\title{
Health benefits of evidence-based biophilic-designed environments: A review
}

\author{
Shih-Han Hung ${ }^{1}$ and Chun-Yen Chang ${ }^{2 *}$ \\ ${ }^{1}$ Doctoral student, Department of Horticulture and Landscape Architecture, National Taiwan University, Taiwan \\ ${ }^{2}$ Professor, Department of Horticulture and Landscape Architecture, National Taiwan University, Taiwan
}

\section{ABSTRACT}

Background and objective: People-nature experiences, which suggest that humans seek connections between nature and other forms of life, were presented by biologist E. O. Wilson in 1984. Biophilic design attributes support environments that can improve human connections to nature. A significant amount of literature on environmental psychology provides empirical evidence that nature benefits humans, and that practical landscape and built environments can be designed to link humans and nature (e.g., the 14 biophilic design patterns). To date, however, there has been no well-done research on reviewing the health benefits of biophilic design.

Methods: The paper provides a narrative review on biophilic design and human health. The scope of this article is limited to biophilic-design books and peer-review articles related to "biophilic design," "evidence-based," "benefits," "health," rather than an attempt to identify universal issues with biophilia hypothesis.

Results: A total of 45 papers were included in our review, which was related to the top five biophilic design patterns and design: the presence of natural images, the presence of plants, visual and non-visual connections to nature, and material connection with nature. These studies were related to physiology and psychology through direct or indirect connections with nature and experiences in space and place.

Conclusion: This study presents two important comparisons of the empirical research on biophilic design and human health that can explain the relationship of people-nature experiences to biophilic design and human health and provides insights into related researches and recommendations for future application of our findings.

Keywords: Biophilic design, urban green spaces, people-nature experiences, individual health benefits

\section{Introduction}

When the COVID-19 pandemic spread worldwide, thousands of people were forced to stay indoors more than usual. Even though research has shown that 120 minutes of contact with nature every week increases health and well-being (White et al., 2019), this phenomenon has significantly affected people's lifestyles; some of these changes include working from home and social distancing in public, each of which reduces opportunities to experience nature. A study by Lopez et al. (2020) described the critical social use of urban parks before and during the
COVID-19 crisis: when one worried about social distancing, crowding, safety, accessibility, etc., it affects one's willingness to visit parks/green spaces. However, research pointed out the increasing number of people start to visit greens even more than before COVID-19. Overall, people consider parks and green spaces, especially the elements of trails, trees, shading, seating, landscaping, and water, to be integral for physical and mental health (Lopez et al., 2020). Despite these recent changes, being in nature can be seen as a beneficial resource for health issues and the human ecology system, which enhances numerous physical and mental health benefits.

Received: December 21, 2020, Revised: January 15, 2021, Accepted: February 16, 2021

First author: Shih-Han Hung, shellyhung6327@gmail.com, (1D https://orcid.org/0000-0002-2937-4255

*Corresponding author: Chun-Yen Chang, cycmail@ntu.edu.tw, (iD) https://orcid.org/0000-0001-6244-1977 
Humans live in the ecosystem and are part of the biosphere, so unsurprisingly, their emotions are closely connected to nature. Humans prefer savanna-like landscapes and positive attitudes that lead them to immerse themselves in nature (Balling and Falk, 1982; Heerwagen et al., 1993). In Biophilia Hypothesis, Wilson (1984) described humans as being deeply connected to nature and lifelike elements. Joye and De Block (2011) further asserted that different genetic predispositions influence biophilic tendencies. Several environmental psychology studies have been conducted into the contributions of nature verse urban areas that support attention restoration, positive emotions, reduced stress, and other physical benefits (Berto, 2005; Barton and Pretty, 2010; Hartig et al., 1991; Kaplan and Kaplan, 1989; Ulrich, 1981; Kim et al, 2016; Marcus and Sachs, 2013; White et al., 2019). Kellert (2018) pointed out human adaptations and design applications that focus on the use of biophilic design attributes, which are included in a built environment to improve the connection to nature, provide health benefits (Browning et al., 2014; Berto et al., 2015). These designs are inspired by natural patterns, attributes, and elements and encourage the use of these features and systems in a built environment to provide humans with the health benefits of a much-needed exposure to nature.

While the literature is replete with discussions related to biophilia and biophilic designs that relate to human health, an analysis of the relationship between nature and health is still lacking. As such, this study will address the following questions: What is a biophilic design, and what is the relationship between biophilic design and health outcomes? In the present study, we will review and evaluate several evidence-based studies and describe the critical role of landscape designers in our everyday contact with nature.

\section{Research Methods}

The goal was to build an evidence-based review of biophilic design and the health benefits thereof according to the broad concept described in 14 Patterns of Biophilic Design (Browning et al., 2014) and the elements presented in Nature by Design: The Practice of Biophilic Design
(Kellert, 2018). Based on those descriptions, we included biophilic design as the variation of a direct and an indirect connection to nature and of a space and place with the health-benefit outcomes of "psychological health" and "physiological health," as all of these describe the relationship between biophilic design and human health. The "cognitive" focuses on cognition and behavioral performance, including concentrating, communication, productivity, etc.; the "psychological health" includes positive emotion, tranquility, relax, low anger, environmental psychological sense of feelings, etc.; the "physiological health" is about low physical tension, such as lower heart rate, blood pressure, pain, etc. However, the "cognitive" outcomes are part of the psychological feeling, in this article, we connect and integrate those into "psychological health", which could be more consistent with the study.

\section{Search and selecting articles}

Based on the core concept of biophilic design (Kellert et al., 2008; Kellert, 2018), this study is a narrative review of disparate literature that describes known health benefits related to biophilic design. The keywords "biophilic design," "evidence-based," "benefits," and "health" were searched on Google Scholar; and 10 relevant studies, review articles, reports, and books were selected to interpret the concept of biophilic design and the relationship thereof to human health and well-being (i.e., Browning et al., 2014; Gillis and Gatersleben, 2015; Grinde and Patil, 2009; Gullone, 2000; Heerwagen and Hase, 2001; Heerwagen, 2006; Kellert et al., 2008; Kellert, 2018; Lumber et al., 2018; Ryan et al., 2014). The snowballing method was then used to further enlarge the body of related articles, particularly those published in SCI, SSCI, A\&HCI journals, etc. A total of 62 articles were chosen; repeated articles, review articles, and irrelative content were excluded, resulting in 45 articles for the next step of the analysis, see Fig. 1. A majority of these papers were from the Journal of Environmental Psychology and Environment and Behavior; and some were from the International Journal of Environmental Research and Public Health, HortTechnology, and Health $\&$ Place, etc., among others. The experiments conducted in these studies typically involved the use of photographs, 


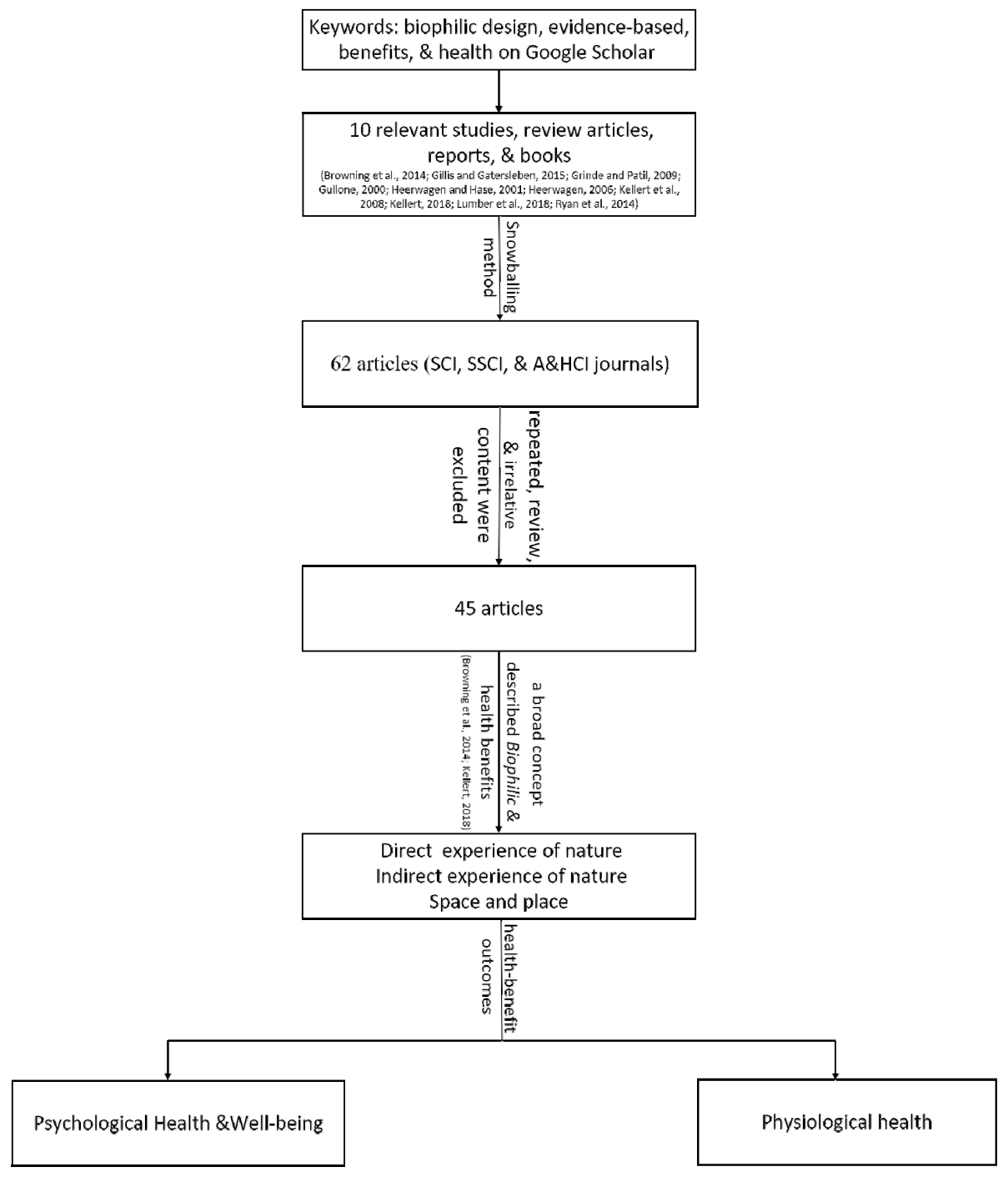

Fig. 1. The flow chart about searching and selecting method.

videos, direct contact with natural and/or urban environments, laboratories, and workplaces; and they utilized a quantitative or qualitative method, including the use of preference questionnaires, the Perceived Restorativeness Scale (PRS), a Profile of Mood States (POMS), Zuckerman Inventory of Personal Reactions (ZIPPER), biofeedback, and functional Magnetic Resonance Imaging (fMRI) to measure the health benefits and brain activities of biophilic designs.

The biophilic design patterns include visual and non-visual connections to nature; non-rhythmic sensory stimuli; thermal and airflow variability; the presence of water, plants, or animals; biomorphic forms and patterns; materials that are connected to nature; complexity and order; the concept of prospect and refuge; the risks and perils; and mystery (Browning et al., 2014). The elements considered were light, air, plants, animals, water, views, landscapes, weather, shapes and forms, materials, textures, colors, images, organized and complexity, prospect and refuge, etc., were integrated with similar concepts into new categories of biophilic design patterns and elements (Table 1); for example, "visual connection to nature" is related to "view" and "landscape," so these were combined into one biophilic pattern.

\section{Data analysis}

The relationships between different natural patterns and elements and health benefits that were described in the lit- 
Table 1. Description of selected biophilic design patterns and elements

\begin{tabular}{|c|c|c|}
\hline $\begin{array}{c}\text { Different } \\
\text { Experiences with } \\
\text { Nature }\end{array}$ & $\begin{array}{l}\text { Biophilic Design Patterns } \\
\text { and Elements }\end{array}$ & $\begin{array}{l}\text { Brief descriptions refer to } \\
\text { Browning et al. (2014) and Kellert (2018) }\end{array}$ \\
\hline \multirow{8}{*}{$\begin{array}{l}\text { Direct experience } \\
\text { with nature } \\
\text { (i.e., nature in the } \\
\text { space) }\end{array}$} & Visual connection to nature & Window views/landscapes; physically being in nature \\
\hline & Non-visual connection to nature & Auditory, haptic, olfactory, or gustatory connection to nature \\
\hline & Non-rhythmic sensory stimuli & Stochastic and ephemeral connections to nature with unanticipated stimuli \\
\hline & Thermal and airflow variability & Weather (e.g., the wind), air temperature, airflow, and air quality can be felt \\
\hline & Presence of water & Water elements are placed in interior/exterior areas \\
\hline & Presence of plants & Plants are placed in interior/exterior areas \\
\hline & Presence of animals & Birds, fish, etc. are placed in the environment \\
\hline & Dynamic and diffuse light & $\begin{array}{l}\text { Place connects to natural light and shadows or is affected by the changeability of } \\
\text { seasons; includes windows in the workplace }\end{array}$ \\
\hline \multirow{4}{*}{$\begin{array}{c}\text { Indirect experience } \\
\text { with nature } \\
\text { (i.e., natural } \\
\text { analogues) }\end{array}$} & Biomorphic forms and patterns & Natural geometries, shapes, forms, and biomimicry styles \\
\hline & Materials connected to nature & Use of colors, textures, and materials \\
\hline & Presence of nature images & $\begin{array}{l}\text { Photos or painting of nature (e.g., water, waterfall, forest, mountain, etc.), especially } \\
\text { in the workplace, schools, or hospitals }\end{array}$ \\
\hline & Simulated natural light and air & Use of artificial lighting to mimic a sense of natural light \\
\hline \multirow{6}{*}{$\begin{array}{c}\text { Space and place } \\
\text { (i.e., nature of the } \\
\text { space) }\end{array}$} & Prospect and refuge & $\begin{array}{l}\text { Seeking to satisfy an innate desire to have the opportunity (i.e., prospect) to review } \\
\text { a space while feeling safe (i.e., refuge) (Appleton, 1975) }\end{array}$ \\
\hline & Organized/complexity & $\begin{array}{l}\text { Rich in detail and diversity with the organization; uniform and featureless without } \\
\text { being boring (e.g., fractal geometries in nature, art, architecture) }\end{array}$ \\
\hline & Mobility and transitional spaces & $\begin{array}{l}\text { Moving from one place to another place (e.g., paths, walks); links the interior to the } \\
\text { exterior; fosters emotional and aesthetic appeal }\end{array}$ \\
\hline & Place & Identifying the place \\
\hline & Integrating parts to create a whole & $\begin{array}{l}\text { Connecting with natural systems and ecosystem; includes awareness of change, age, } \\
\text { and the patina of time in the environment; coherence in the environment }\end{array}$ \\
\hline & Risk/peril/mystery & Arouses attention and curiosity, refreshes memory, improves problem-solving skills \\
\hline
\end{tabular}

erature and the experimental stimuli were analyzed to classify the environment into different biophilic patterns and elements. We then used Microsoft Excel (Office 2016) to integrate the results into one of the following categories: psychological health and well-being and physiological health.

\section{Descriptive analysis of biophilic pattems and elements}

A total of 45 peer-reviewed studies that re-examined the interactions between the environment and human health benefits were selected. Of the proposed biophilic design patterns and elements, we determined that "the presence of natural images" (24\%), "the presence of plants" (14\%), "non-visual connections to nature" (13\%), and "visual connections to nature" (11\%) and, "material connection with nature" (11\%) etc. were the most frequently used in experimental research designs and related health benefits (Fig. 2).

\section{Content analysis of the $\mathbf{4 5}$ articles}

A brief description of the content analysis showed in Table 2. According to the contents, we found out there were 43 articles tested about the psychological outcomes by using the patterns of "direct and indirect experience of nature" and "space and place". The psychological outcomes include increasing productivity, creativity, concentration, attention restoration, positive mood, lower tension, and anxiety, etc. Eighteen articles tested the physical index with the biophilic patterns, such as low heart rate, pain, decrease diastolic blood pressure (DBP), systolic blood pressure (SBP), skin conductance, etc. Besides, we found out the researchers would evaluate several health benefits or the similar concepts use a different method to test, for example, "stress" could be tested in the questionnaire or physical stress (i.e. DBP or SBP, etc.). Therefore, there were sixteen 
articles both discuss the psychological and physical labels in psychological and physical outcomes. outcomes. We would categorize those benefits into both

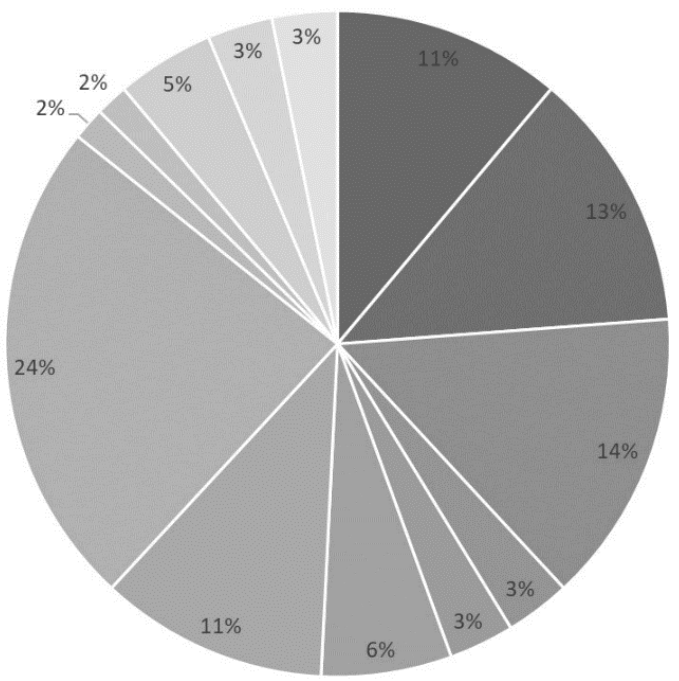

- Visual connection to nature

- Nonvisual connection to nature

- Presence of Plant

- Presence of Animals

- Dynamic \&diffuse

= Biomorphic forms \& patterns

- Material connection with nature

= Presence of natural images

- Simulated natural light and air

- Prospect and refuge

= Mobility \& Transitional spaces

$=$ Place attachment

= Risk/Peril/Mystery

Fig. 2. Proportions of different patterns in biophilic design.

Table 2. A brief description of content analysis of 62 articles about the psychological and physical outcomes

\begin{tabular}{|c|c|c|c|}
\hline & Selected & Brief Content Analysis & Reference \\
\hline 1 & $\mathrm{~V}$ & nursing / hospital / windows / light / psychological / physical & Zadeh et al., 2014 \\
\hline 2 & $\mathrm{~V}$ & children / school / windows / light / psychological / physical & Küller \& Lindsten, 1992 \\
\hline 3 & $\mathrm{~V}$ & individual / viewing photos-urban \& natural landscape + sound / psychological / physical & Ulrich et al., 1991 \\
\hline 4 & $\mathrm{~V}$ & $\begin{array}{l}\text { students \& staff / viewing photos- water features, green spaces, buildings, animals, plants, } \\
\text { people / psychological }\end{array}$ & White et al., 2010 \\
\hline 5 & $\mathrm{~V}$ & student / sound-nature urban environmental sound / psychological / physical & Alvarsson et al., 2010 \\
\hline 6 & $\mathrm{~V}$ & individual / office space/ real potted plants / psychological & Larsen et al., 1998 \\
\hline 7 & $\mathrm{~V}$ & staff / real office design / planting / psychological & Nieuwenhuis et al., 2014 \\
\hline 8 & $\mathrm{~V}$ & individual / real potted plants / physical & Qin et al., 2014 \\
\hline 9 & $\mathrm{~V}$ & individual / viewing photos-city, nature, weather type, bright / psychological & Beute \& de Kort, 2013 \\
\hline 10 & $\mathrm{~V}$ & concept* / psychological & Kaplan, 1995 \\
\hline 11 & $\mathrm{~V}$ & patient / hospital / window viewings with or without plants / psychological / physical & Ulrich, 1984 \\
\hline 12 & $\mathrm{~V}$ & students / indoor-window view / natural photos / psychological & Felsten, 2009 \\
\hline 13 & $\mathrm{~V}$ & residents / simulation photos / psychological & White \& Gatersleben, 2011 \\
\hline 14 & $\mathrm{~V}$ & students / viewing photos-urban roof \& simulation ones / psychological & Lee et al., 2015 \\
\hline 15 & $\mathrm{~V}$ & students / real nature and urban environment-walking \& sidewalk / psychological / physical & Hartig et al., 2003 \\
\hline 16 & $\mathrm{~V}$ & $\begin{array}{l}\text { participants in school / video-urban \& forest trail with/without water+ sound / } \\
\text { psychological / physical }\end{array}$ & Van den Berg et al., 2003 \\
\hline 17 & $\mathrm{~V}$ & participants in school / photos-beach, highway/ psychological / physical & Hunter et al., 2010 \\
\hline 18 & $\mathrm{~V}$ & students \& school staffs / viewing photos- urban, country, sea, etc. + voice / psychological & Pheasant et al., 2010 \\
\hline 19 & $\mathrm{X}$ & review articles & Velarde et al., 2007 \\
\hline 20 & $\mathrm{X}$ & repeated articles in 10 main list & Kellert, 2018 \\
\hline
\end{tabular}


Table 2. (continued)

\begin{tabular}{|c|c|c|c|}
\hline & Selected & Brief Content Analysis & Reference \\
\hline 21 & $\mathrm{~V}$ & office employees / indoor plants / psychological & Bringslimark et al., 2007 \\
\hline 22 & $\mathrm{~V}$ & staffs / real office design/plantings / psychological & Shoemaker et al., 1993 \\
\hline 23 & $\mathrm{~V}$ & students / scenario of hospital plantings \& city map / psychological & Dijkstra et al., 2008 \\
\hline 24 & $\mathrm{~V}$ & students / simulated office photos-plants / psychological / physical & Chang \& Chen, 2005 \\
\hline 25 & $\mathrm{X}$ & review articles & Browning et al., 2014 \\
\hline 26 & $\mathrm{~V}$ & muti-analysis of researches / psychological & Barton, \& Pretty, 2010 \\
\hline 27 & $\mathrm{~V}$ & school staffs / nature \& urban photos / psychological / physical & Brown et al., 2013 \\
\hline 28 & $\mathrm{X}$ & review articles & Van den Berg et al., 2007 \\
\hline 29 & $\mathrm{~V}$ & participants in school / real space simulation office / river sound / noise / physical & Jahncke et al., 2011 \\
\hline 30 & $\mathrm{~V}$ & college students / touch real plants / psychological / physical & Koga \& Iwasaki, 2013 \\
\hline 31 & $\mathrm{~V}$ & consumers / real fish tank / behavior analysis / psychological & Windhager et al., 2011 \\
\hline 32 & $\mathrm{X}$ & repeated articles & Hartig et al., 2003 \\
\hline 33 & $\mathrm{~V}$ & elderlies / local park / psychological / physical & Orsega-Smith et al., 2004 \\
\hline 34 & $\mathrm{X}$ & repeated articles in 10 main list & Lumber et al., 2018 \\
\hline 35 & $\mathrm{~V}$ & concept* / psychological & Schatz \& Bowers 2005 \\
\hline 36 & $\mathrm{X}$ & review articles & Edwards \& Torcellini, 2002 \\
\hline 37 & $\mathrm{X}$ & review articles & Fitzgerald \& Danner, 2012 \\
\hline 38 & $\mathrm{~V}$ & students / performance / daylight / psychological & Nicklas \& Bailey, 1996 \\
\hline 39 & $\mathrm{X}$ & repeated articles in 10 main list & Kellert et al., 2008 \\
\hline 40 & $\mathrm{X}$ & repeated articles & Bringslimark et al., 2007 \\
\hline 41 & $\mathrm{~V}$ & residents / qualitative research / sound- birds, natural sound / psychological & Ratcliffe et al., 2013 \\
\hline 42 & $\mathrm{~V}$ & staffs / simulating real office environment / plantings / psychological & Knight \& Haslam, 2010 \\
\hline 43 & $\mathrm{~V}$ & clinic / nature park / video / psychological / physical & Kjellgren \& Buhrkall, 2010 \\
\hline 44 & $\mathrm{~V}$ & students/ simulated wood ratio / psychological /physical & Tsunetsugu et al., 2007 \\
\hline 45 & $\mathrm{~V}$ & nursing / hospital / photos- wood / psychological & Nyrud et al., 2014 \\
\hline 46 & $\mathrm{~V}$ & individuals / color (green, red, gray, etc.) / psychological & Lichtenfeld et al., 2012 \\
\hline 47 & $\mathrm{~V}$ & individuals / fractal dimension / computer model / psychological & Hagerhall et al., 2004 \\
\hline 48 & $\mathrm{~V}$ & concept* / psychological & Joye, 2007 \\
\hline 49 & $\mathrm{~V}$ & individual / photos, walking / psychological / physical & Gatersleben \& Andrews, 2013 \\
\hline 50 & $\mathrm{X}$ & irrelative content/development scale & Grahn \& Stigsdotter, 2010 \\
\hline 51 & $\mathrm{~V}$ & students / photos-forest / psychological & Herzog \& Bryce, 2007 \\
\hline 52 & $\mathrm{X}$ & book & Salingaros, 2017 \\
\hline 53 & $\mathrm{~V}$ & residents / online questionnaires / favorite places / psychological & Korpela et al., 2009 \\
\hline 54 & $\mathrm{X}$ & $\begin{array}{l}\text { irrelative content / description the relationship between favorite places and restorative, } \\
\text { but hard to categorize into biophilic elements and patterns }\end{array}$ & Korpela et al., 2001 \\
\hline 55 & $\mathrm{~V}$ & students / photos-forest / psychological & Herzog \& Kropscott, 2004 \\
\hline 56 & $\mathrm{X}$ & $\begin{array}{l}\text { irrelative content/focus on the activity types in physical and social situation to predict } \\
\text { perceived danger, tension, and fear }\end{array}$ & Rapee, 1997 \\
\hline 57 & $\mathrm{~V}$ & individual / content analysis / positive \& negative emotions / natural scenes / psychological & Van den Berg \& Ter Heijne, 2005 \\
\hline 58 & $\mathrm{X}$ & irrelative content & Mehta et al., 2012 \\
\hline 59 & $\mathrm{X}$ & review articles & Tsunetsugu et al., 2010 \\
\hline 60 & $\mathrm{~V}$ & concept* / psychological / physical & Reddy et al., 2012 \\
\hline 61 & $\mathrm{X}$ & repeated articles & Qin et al., 2014 \\
\hline 62 & $\mathrm{~V}$ & staffs / real-like office / plantings / interview / psychological & Thomsen et al., 2011 \\
\hline
\end{tabular}




\section{Results and Discussion}

\section{Health benefits of biophilic patterns: Psychological health and well-being}

Table 3 shows the psychological health and well-being outcomes of biophilic designs, including but not limited to feeling positive emotions and pleasure, attention restoration, preference, feelings of relaxation, and decrease a sense of anger, etc. Moreover, it includes increasing cognitive functionality and performance.

Several studies found that visual and non-visual connections to nature and direct experiences with nature that is made possible by the presence of plants have positively affect psychological health and well-being in outdoor environments and interior designs (e.g., Barton and Pretty, 2010; Hartig et al., 2003; Larsen et al., 1998; Orsega-Smith et al., 2004; Pheasant et al., 2010; Thomsen et al., 2011); those results are in line with two environmental psychological theories - Attention Restoration Theory (Kaplan and Kaplan, 1989) and the Stress Reduction Theory (Ulrich et al., 1991), which explain two ways in which contact with nature improves people's psychological states; the presence of plants in an office also reduces perceived stress (Dijkstra et al., 2008; Larsen et al., 1998). Moreover, in an office setting and a hospital, exposure to nature and sunlight through a window view can improve employee performance and mood (Zadeh et al., 2014); and patients are able to recover better from surgery (Ulrich, 1984). Besides, much of the literature described how a visual connection to nature and the presence of plants in an outdoor/indoor environment, also referred to as "direct experience with nature," can improve cognitive functionality and performance by increasing communication, concentration, and productivity, (e.g., Shoemaker et al., 1992; Thomsen et al., 2011; Larsen et al., 1998; Zadeh et al., 2004). One of the cited studies highlighted that being physically present in nature not only could stimulate sensory perceptions and feelings of well-being, but also alters states-of-consciousness, especially feelings of relaxation (Kjellgren and Buhrkall, 2010).

However, these studies yielded few findings between the psychological impact of indirect experiences with nature, such as biomorphic forms and patterns, materials, and natural images that could enhance creativity and productivity (Joye, 2007; Lichtenfeld et al., 2012). Schatz and Bowers (2005) investigated how color design in the workplace influences worker moods, performance, productivity, and satisfaction. Tsunetsugu et al. (2007) discovered that an interior that is composed of $45 \%$ wood imbues a sense of comfort, naturalness, and restfulness; these results are similar to those of a study that incorporated natural elements in a hospital setting (Nyrud et al., 2014).

"Space and Place" is defined as the nature of the space. Visual connections to nature and exposure to natural environments with high prospect levels and low refuge levels are restorative; alternately, exposure to natural environments with low prospect levels and high refuge levels aren't restorative, however, could increase negative emotion, physical stress, and attention fatigue (Gatersleben and Andrews, 2013). Whether in the field of in laboratory experiments, the feeling of being connected to nature in a naturally designed setting, as opposed to an urban setting, has been shown to markedly improve psychological health and well-being by affecting pleasure and emotion, restoring attention, and reducing stress (Browning et al., 2014; Hartig et al., 2003; Ryan et al., 2014; White et al., 2010); furthermore, a natural-setting space can evoke a sense of mystery, attraction, and one's preference (Herzog and Bryce, 2007; Herzog and Kropscott, 2004). Rapee (1997) found, however, that perceived threats in nature-based activities, such as on a mountain, in an alley or forest, or while scuba diving, can lead to feelings of anxiety and fear.

\section{Biophilic patterns: Physiological health benefits}

Table 4 shows the physiological effects that were identified using instruments to detect heart rate, blood pressure, cortisol levels, and other physiological indicators, in addition to a questionnaire intended to understand stress reactions in the human body. These findings were similar to those for psychological health and well-being: Visual and non-visual connections to nature and the presence of plants and light reduces stress, lowers the heart rate, and decreases blood pressure, among other benefits (Hartig et al., 2003; Küller and Lindsten, 1992; Ulrich, 1984; Ulrich 


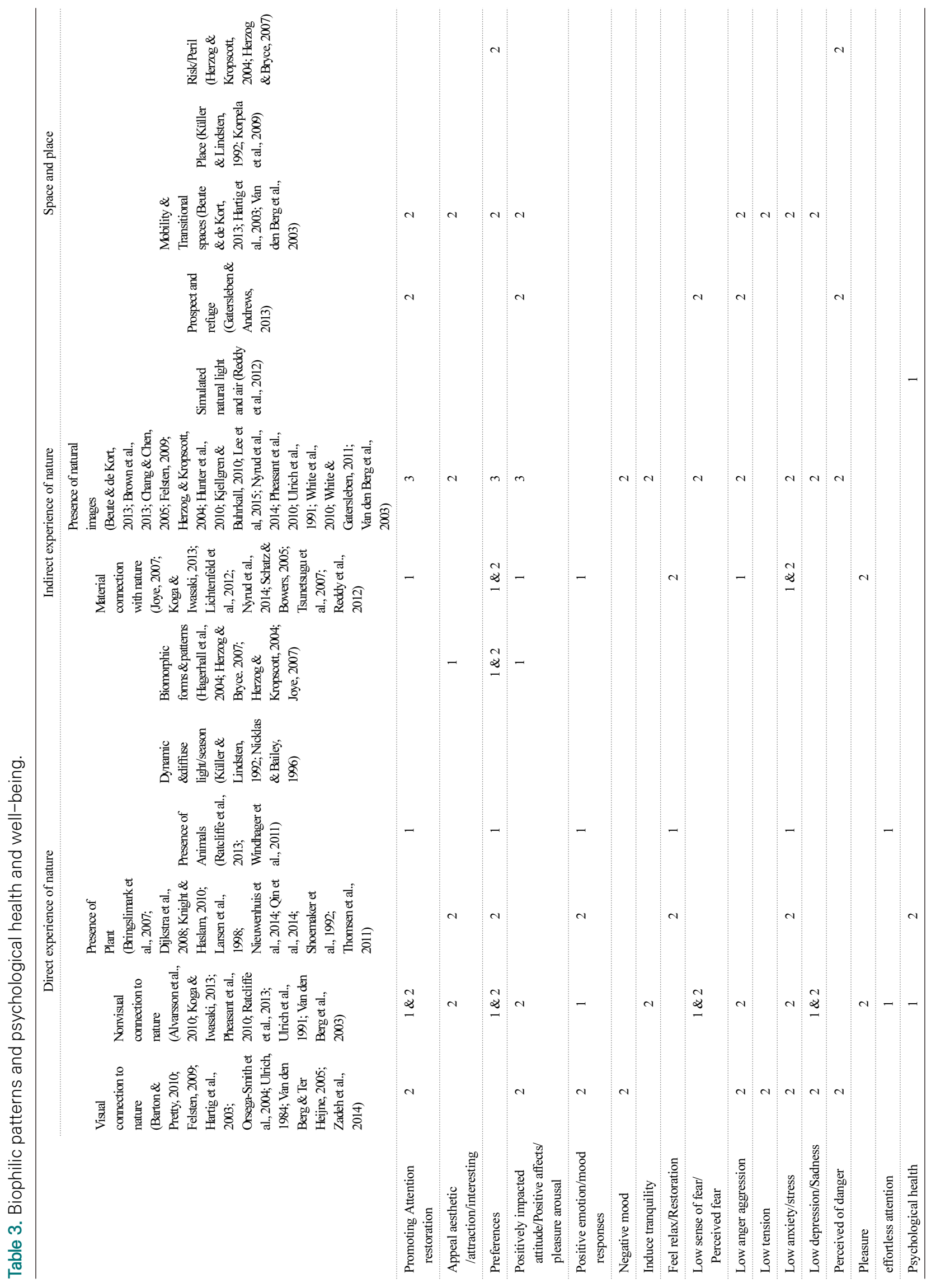


$\mid$

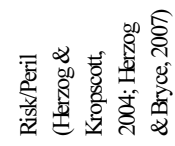

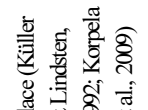

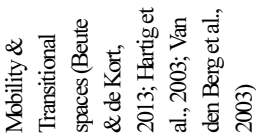

总离

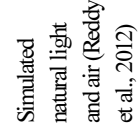

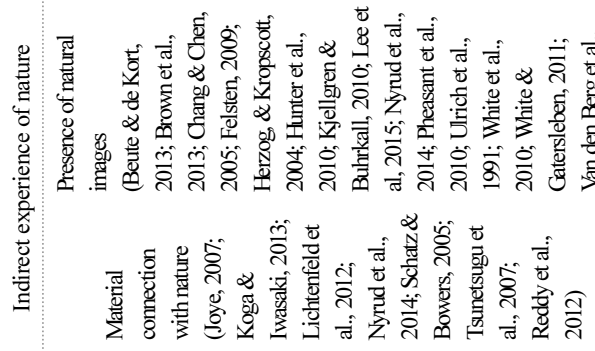

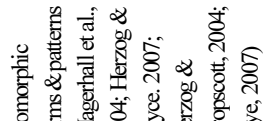

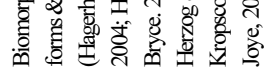

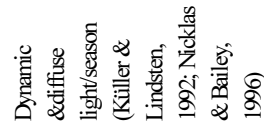

岁焉 离

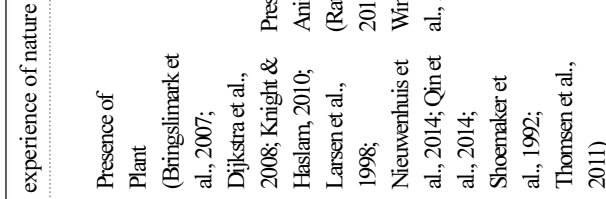

总:

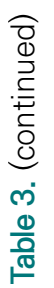

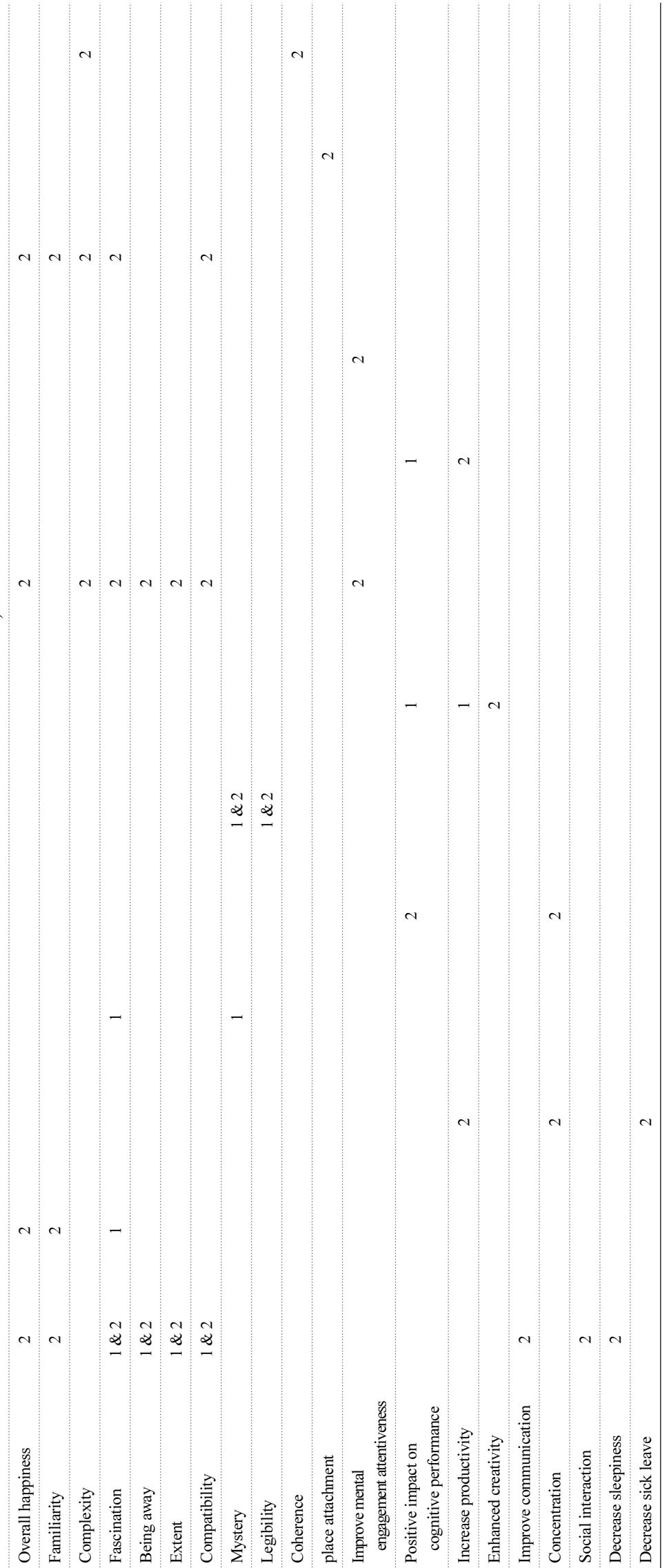

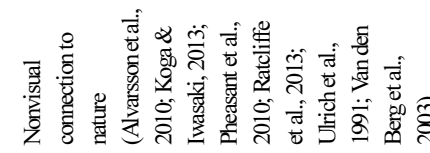

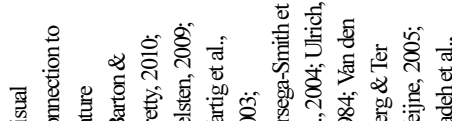

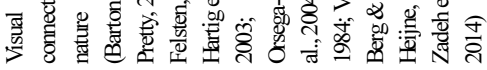

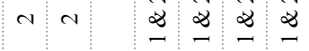




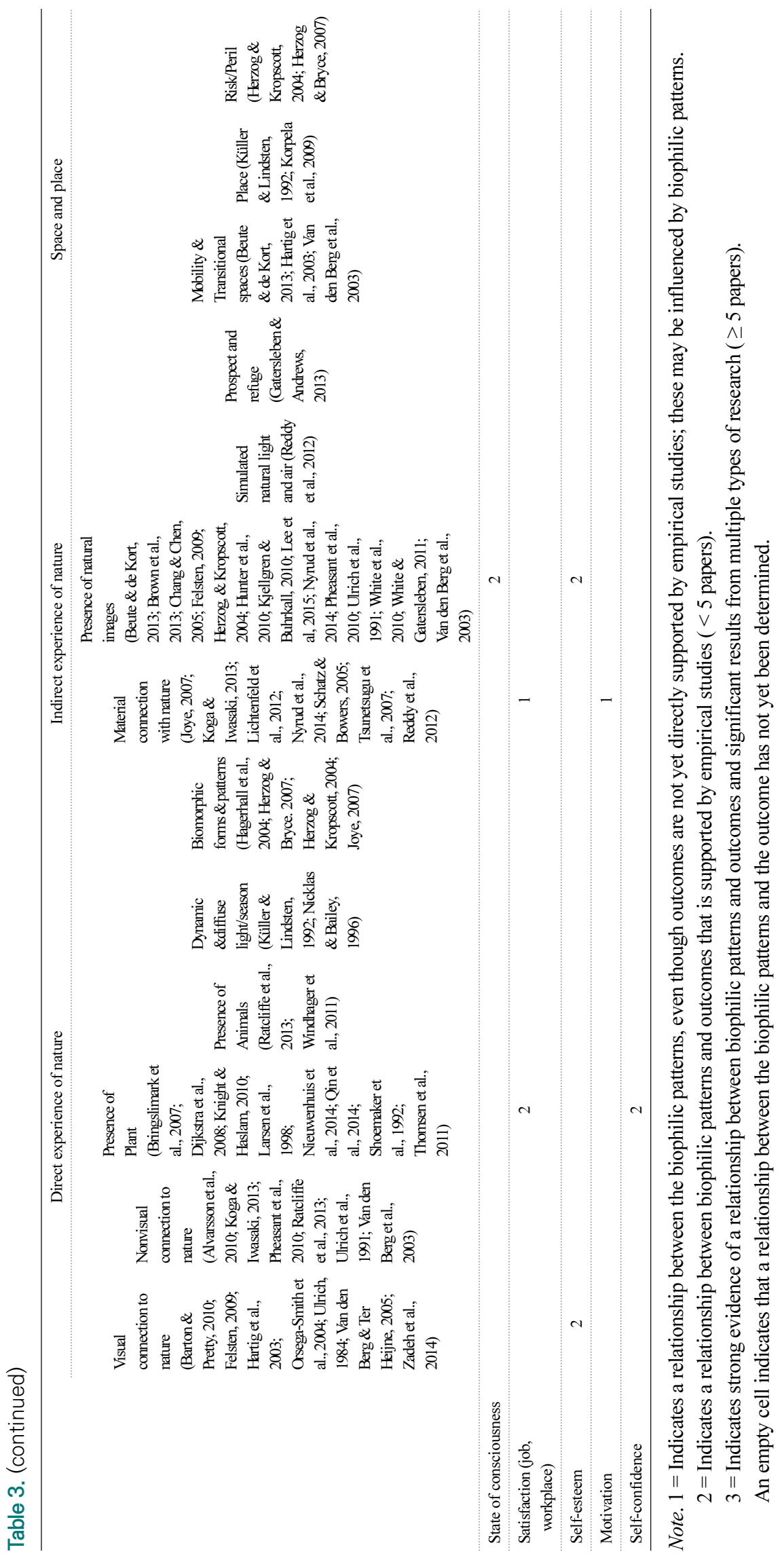


Table 4. Biophilic patterns and physiological health

\begin{tabular}{|c|c|c|c|c|c|c|c|c|c|}
\hline & \multicolumn{4}{|c|}{ Direct experience of nature } & \multicolumn{3}{|c|}{ Indirect experience of nature } & \multicolumn{2}{|c|}{ Space and place } \\
\hline & $\begin{array}{l}\text { Visual } \\
\text { connection } \\
\text { to nature } \\
\text { (Hartig et al., } \\
2003 \text {; } \\
\text { Orsega-Smith } \\
\text { et al., 2004; } \\
\text { Zadeh et al., } \\
\text { 2014) }\end{array}$ & $\begin{array}{l}\text { Nonvisual } \\
\text { connection } \\
\text { to nature } \\
\text { (Alvarsson } \\
\text { et al., 2010; } \\
\text { Jahncke et } \\
\text { al., 2011; } \\
\text { Reddy et al., } \\
\text { 2012; Ulrich } \\
\text { et al., 1991) }\end{array}$ & $\begin{array}{l}\text { Presence of } \\
\text { Plant (Qin et } \\
\text { al., 2014; } \\
\text { Thomsen et } \\
\text { al., 2011; } \\
\text { Ulrich, } \\
\text { 1984) }\end{array}$ & $\begin{array}{l}\text { Dynamic } \\
\text { \&diffuse } \\
\text { light/season } \\
\text { (Küller \& } \\
\text { Lindsten, } \\
\text { 1992) }\end{array}$ & $\begin{array}{l}\text { Material } \\
\text { connection } \\
\text { with nature } \\
\text { (Joye, } \\
\text { 2007; Koga } \\
\text { \& Iwasaki, } \\
\text { 2013; } \\
\text { Tsunetsugu } \\
\text { et al., 2007) }\end{array}$ & $\begin{array}{l}\text { Presence of } \\
\text { natural images } \\
\text { (Brown et al., } \\
\text { 2013; Chang \& } \\
\text { Chen, 2005; } \\
\text { Hunter et al., } \\
\text { 2010; Kjellgren \& } \\
\text { Buhrkall, 2010; } \\
\text { Tsunetsugu et al., } \\
\text { 2007; Ulrich et al., } \\
\text { 1991) }\end{array}$ & $\begin{array}{l}\text { Simulated } \\
\text { natural } \\
\text { light and } \\
\text { air (Reddy } \\
\text { et al., } \\
\text { 2012) }\end{array}$ & $\begin{array}{l}\text { Prospect } \\
\text { and refuge } \\
\text { (Gatersleben } \\
\text { \& Andrews, } \\
2013 \text { ) }\end{array}$ & $\begin{array}{l}\text { Mobility \& } \\
\text { Transitional } \\
\text { spaces (Van } \\
\text { den Berg et } \\
\text { al., 2003) }\end{array}$ \\
\hline Low blood pressure & & & & & 2 & 2 & & & \\
\hline Low heart rate (BVP) & 2 & & & & & 2 & & 2 & \\
\hline SDRR & & & & & & 2 & & & \\
\hline Decrease in diastolic blood pressure (DBP) & 2 & & & & 2 & 2 & & & 2 \\
\hline Decrease in systolic blood pressure (SBP) & 2 & & & & 2 & 2 & & & 2 \\
\hline Frontalis muscle tension (EMG) & & 2 & & & & 2 & & & \\
\hline Electroencephalogram (EEG) & & & 2 & & & 2 & & & \\
\hline Less pain & & & & & & 2 & & & \\
\hline Reduce skin conductance level(SCL) & 2 & 2 & & & & & & & \\
\hline Gain energy & & & & & & 2 & & & \\
\hline overall (Perceived) physical health & 2 & 2 & 2 & & & & 1 & & \\
\hline Brain activity & & & & & & $1 \& 2$ & & & \\
\hline Body temperature & 2 & & & & & & & & \\
\hline Blood oxygen & 2 & & & & & & & & \\
\hline Cortisol & & & & 2 & & & & & \\
\hline Pulse transit time(PTT) & & 2 & & 2 & & & & & \\
\hline Oxyhaemoglobin & & & & 2 & 2 & & & & \\
\hline
\end{tabular}

et al., 1991; Zadeh et al., 2014). Moreover, Pheasant et al. (2010) indicated that the perceived stimulation from the environment and the visual-auditory interactions thereof can affect a sense of tranquility; this is in line with Hunter et al. (2010), who found out that, compared to viewing a freeway, viewing a beach influences a stronger sense of tranquility and activates the connection between the auditory and perception areas in the brain. Tsunetsugu et al. (2007) also concluded that the use of natural analogs, such as natural materials, can lead to stress reduction.

\section{Conclusion}

This review collected and integrated the 18 patterns of biophilic design with the 18 physiological health outcomes and 42 psychological outcomes, including 14 cognitive functionality and performance; and concluded that most of the cited research used natural images (e.g., mountains, forests, water elements), the presence of plants in an interior environment, and a visual connection to nature in an indoor environment as methods to investigate the relationship between nature and human health. Moreover, some studies used non-visual nature connections such as natural sounds or textures to determine benefits with nature. These studies were selected because they present evidence-based conclusions that natural patterns and elements, which are associated with biophilic design principles that support human adaptation, engagement, and immersion in nature, improve human health and provide multiple benefits for humans in a built environment (e.g., increase productivity and provide aesthetic appeal, emotional attachment, and physical and social dimensions) (Kellert, 2018).

Five patterns were determined to limit the findings in 
this study: non-rhythmic sensory stimuli, thermal and airflow variability, the presence of water, organized/complexity, and integrating parts to create a whole. The empty cells in Table 2-4 indicate a possible direction for researchers who wish to test these relationships; for example, Kellert (2018) explained that direct or indirect connections to water, such as pictures and videos of wetlands, ponds, and waterfalls, provides human-nature experiences and the psychological and physiological benefits thereof. White et al. (2010) also asserted that photographs of water, plants, animals, and other elements of nature can influence a person's preferences, affections, and levels of restorativeness, which can lead to further research to investigate the benefits of actual exposure to landscapes and water to psychological and physiological health. Patterns of thermal and airflow variability are associated with weather and good atmospheric conditions, which is linked to human-nature experiences (Browning et al., 2014; Kellert, 2018); future studies could shed light on the micro-climate indicators in a built environment that influence human feelings. Finally, the different forms of landscapes (e.g., English, French, Japanese, and Chinese gardens), the organization and complexity thereof, and the pattern of integrating parts of those landscape patterns to create a whole that can affect human health warrants further investigation.

The concept of biophilia is a psychological feeling of connecting nature and humans; the biophilic design is a method of using nature and natural-like patterns and elements that enhance the opportunity for humans to exposure to nature in the built environment. It can be used to construct a framework a people-nature experiences, to verify the impact that these biophilic patterns have on human physiological and psychological health in urban green spaces. More specifically, the research found out the 18 patterns and elements of biophilic design and health could be widely used in visual and non-visual connections to nature, the presence of natural images, natural material, and plants in outdoor or interior environment, which could reduce psychological and physical stress, recover attention restoration, and improve positive emotion and aesthetic attraction, etc. Those findings are related to the concept of restorativeness environment (i.e. being away, fascination, extent, and compatibility), landscape preference (i.e. legi- bility, mystery, complexity, coherence), and the stress reduction theory. By better understanding, these relationships and the related theories in environmental psychology, the methods that incorporate biophilic design measures to improve the landscapes and urban designs can be devised.

Our findings as using the biophilic patterns and elements might be linked to the Sustainable Development Goals (SDGs) of Goal 3 for the action of "ensuring healthy lives and promoting well-being", Goal 11 for "making cities and human settlements inclusive, safe, resilient and sustainable", and Goal 15 for "protecting, restoring and promoting sustainable of ecosystems on land". Those policies are insights to link biophilic design as an approach of restorativeness and ecological environment for balancing human and species in the built environment.

\section{References}

Appleton, J. 1975. The experience of place. London: Wiley. Alvarsson, J.J., S. Wiens and M.E. Nilsson. 2010. Stress Recovery during exposure to nature sound and environmental noise. Int. J. Environ. Res. Public Health. 7(3):1036-1046. https://doi.org/10.3390/ijerph7031036

Balling, J.D. and J.H. Falk. 1982. Development of visual preference for natural environments. Environ. Behav. 14(1):5-28. https://doi.org/10.1177/0013916582141001

Barton, J. and J. Pretty. 2010. What is the best dose of nature and green exercise for improving mental health? A multi-study analysis. Environ. Sci. Technol. 44(10): 947-3955. https://doi.org/10.1021/es903183r

Berto, R. 2005. Exposure to restorative environments helps restore attentional capacity. J. Environ. Psychol. 25(3): 49-259. https://doi.org/10.1016/j.jenvp.2005.07.001

Berto, R., G. Barbiero, M. Pasini, and P. Unema. 2015. Biophilic design triggers fascination and enhances psychological restoration in the urban environment. J. Biourbanism. 1:27-34.

Beute, F. and Y.A.W. de Kort. 2013. Let the sun shine! Measuring explicit and implicit preference for environments differing in naturalness, weather type and brightness. J. Environ. Psychol. 36:162-178. https://doi.org/10.1016 /j.jenvp.2013.07.016 
Bringslimark, T., T. Hartig, and G.G. Patil. 2007. Psychological benefits of indoor plants in workplaces: Putting experimental results into context. HortScience. 42(3):581-587. https://doi.org/10.21273/HORTSCI.42.3.581

Brown, D.K., J.L. Barton, and V.F. Gladwell. 2013. Viewing nature scenes positively affects recovery of autonomic function following acute-mental stress. Environ. Sci. Technol. 47(11):5562-5569. https://doi.org/10.1021/es3 $05019 \mathrm{p}$

Browning, W.D., C.O. Ryan, and J.O. Clancy. 2014. 14 Patterns of Biophilic Design. New York, NY: Terrapin Bright Green LLC.

Chang, C.Y. and P.K. Chen. 2005. Human response to window views and indoor plants in the workplace. HortScience. 40(5):1354-1359. https://doi.org/10.21273 /HORTSCI.40.5.1354

Dijkstra, K., M.E. Pieterse, and A. Pruyn. 2008. Stressreducing effects of indoor plants in the built healthcare environment: The mediating role of perceived attractiveness. Prev. Med. 47(3):279-283. https://doi.org/10.1016/ j.ypmed.2008.01.013

Edwards, L. and P. Torcellini. 2002. Literature review of the effects of natural light on building occupants. (No. NREL/TP-550-30769). National Renewable Energy Lab., Golden, CO.(US).

Felsten, G. 2009. Where to take a study break on the college campus: An attention restoration theory perspective. J. Environ. Psychol. 29(1):160-167. https://doi.org/10.101 6/j.jenvp.2008.11.006

Fitzgerald, C.J. and K.M. Danner. 2012. Evolution in the office: How evolutionary psychology can increase employee health, happiness, and productivity. Evol. Psychol. 10(5):147470491201000502. https://doi.org/10.1177/14 7470491201000502

Gatersleben, B. and M. Andrews. 2013. When walking in nature is not restorative-The role of prospect and refuge. Health Place. 20:91-101. https://doi.org/10.1016/j.health place.2013.01.001

Gillis, K. and B. Gatersleben. 2015. A review of psychological literature on the health and wellbeing benefits of biophilic design. Buildings. 5(3):948-963. https://doi. org/10.3390/buildings5030948

Grinde, B. and G.G. Patil. 2009. Biophilia: Does visual contact with nature impact on health and well-being?
Int. J. Environ. Res. Public Health. 6(9):2332-2343. https://doi.org/10.3390/ijerph6092332

Grahn, P. and U. K. Stigsdotter. 2010. The relation between perceived sensory dimensions of urban green space and stress restoration. Landsc Urban Plan. 94(3-4): 264-275. https://doi.org/10.1016/j.landurbplan.2009.10.012

Gullone, E. 2000. The biophilia hypothesis and life in the 21st century: Increasing mental health or increasing pathology? J. Happiness Stud. 1(3):293-322. https://doi. org/10.1023/A:1010043827986

Hagerhall, C.M., T. Purcell, and R. Taylor. 2004. Fractal dimension of landscape silhouette outlines as a predictor of landscape preference. J. Environ. Psychol. 24(2): 247-255. https://doi.org/10.1016/j.jenvp.2003.12.004

Hartig, T., M. Mang, and G.W. Evans. 1991. Restorative effects of natural environment experiences. Environ Behav. 23(1):3-26. https://doi.org/10.1177/0013916591231001

Hartig, T., G.W., Evans, L.D. Jamner, D.S. Davis, and T. Gärling. 2003. Tracking restoration in natural and urban field settings. J. Environ. Psychol. 23(2):109-123. https://doi.org/10.1016/S0272-4944(02)00109-3

Heerwagen, J.H., G.H. Orians, S.R. Kellert, and E.O. Wilson. 1993. The biophilia hypothesis. Washington, D.C.: Island Press.

Heerwagen, J. and B. Hase. 2001. Building biophilia: Connecting people to nature in building design. $\mathrm{ED}+\mathrm{C}$. 3:30-36.

Heerwagen, J. H. 2006. Investing in people: The social benefits of sustainable design. Presented at Rethinking Sustainable Construction 2006, Sarasota, Florida. 19-22.

Herzog, T.R. and L.S. Kropscott. 2004. Legibility, mystery, and visual access as predictors of preference and perceived danger in forest settings without pathways. Environ. Behav. 36(5):659-677. https://doi.org/10.1177/0013916 504264138

Herzog, T.R. and A.G. Bryce. 2007. Mystery and preference in within-forest settings. Environ. Behav. 39(6): 779-796. https://doi.org/10.1177/0013916506298796

Hunter, M.D., S.B. Eickhoff, R.J. Pheasant, M.J. Douglas, G.R. Watts, T.F.D. Farrow, D. Hyland, J. Kang, I.D. Wilkinson, K.V. Horoshenkov, and P.W.R. Woodruff. 2010. The state of tranquility: Subjective perception is shaped by contextual modulation of auditory connectivity. 
NeuroImage. 53(2):611-618. https://doi.org/10.1016/j.ne uroimage.2010.06.053

Jahncke, H., S. Hygge, N. Halin, A. M. Green, and K. Dimberg. 2011. Open-plan office noise: Cognitive performance and restoration. J. Environ. Psychol. 31(4): 373-382. https://doi.org/10.1016/j.jenvp.2011.07.002

Joye, Y. 2007. Architectural lessons from environmental psychology: The case of biophilic architecture. Rev. Gen. Psychol. 11(4):305-328. https://doi.org/10.1037/1089-26 80.11.4.305

Joye, Y. and A. De Block. 2011. 'Nature and I are two': A critical examination of the biophilia hypothesis. Environ. Values. 20(2):189-215. https://doi.org/10.3197/0963271 11X12997574391724

Kaplan, R. and S. Kaplan. 1989. The Experience of Nature: A Psychological Perspective. Cambridge, UK: Cambridge University Press. Retrieved from https://archive.org/details/experienceofnatu00kapl

Kaplan, S. 1995. The restorative benefits of nature: Toward an integrative framework. J. Environ. Psychol. 15(3): 169-182. https://doi.org/10.1016/0272-4944(95)90001-2

Kellert, S.R., J. Heerwagen, and M. Mador. 2008. Biophilic Design: The Theory, Science and Practice of Bringing Buildings to Life. Hoboken, NJ: John Wiley \& Sons, Inc.

Kellert, S.R. 2018. Nature by Design: The Practice of Biophilic Design. New Haven, CT: Yale University Press.

Kim, J. H., C. Lee, and W. Sohn. 2016. Urban natural environment, obesity, and health-related quality of life among Hispanic children living in inner-city neighborhoods. Int. J. Environ. Res. Public Health. 13(1), 121. https://doi.org/10.3390/ijerph13010121

Kjellgren, A. and H. Buhrkall. 2010. A comparison of the restorative effect of a natural environment with that of a simulated natural environment. J. Environ. Psychol. 30(4):464-472. https://doi.org/10.1016/j.jenvp.2010.01.011

Knight, C. and S.A. Haslam. 2010. The relative merits of lean, enriched, and empowered offices: An experimental examination of the impact of workspace management strategies on well-being and productivity. J. Exp. Psychol. Appl. 16(2):158-172. https://doi.org/10.1037/a0019292

Koga, K. and Y. Iwasaki. 2013. Psychological and physiological effect in humans of touching plant foliageUsing the semantic differential method and cerebral ac- tivity as indicators. J. Physiol. Anthropol. 32(1):7. https://doi.org/10.1186/1880-6805-32-7

Korpela, K.M., M. Ylén, L. Tyrväinen, and H. Silvennoinen. 2009. Stability of self-reported favourite places and place attachment over a 10-month period. J. Environ. Psychol. 29(1):95-100. https://doi.org/10.1016/j.jenvp.2008.05.008

Küller, R. and C. Lindsten. 1992. Health and behavior of children in classrooms with and without windows. J. Environ. Psychol. 12(4):305-317. https://doi.org/10.101 6/S0272-4944(05)80079-9

Larsen, L., J. Adams, B. Deal, B.S. Kweon, and E. Tyler. 1998. Plants in the workplace: The effects of plant density on productivity, attitudes, and perceptions. Environ. Behav. 30(3):261-281. https://doi.org/10.1177/0013916 59803000301

Lee, K.E., K.J.H. Williams, L.D. Sargent, N.S.G. Williams, and K.A. Johnson. 2015. 40-second green roof views sustain attention: The role of micro-breaks in attention restoration. J. Environ. Psychol. 42:182-189. https://doi. org/10.1016/j.jenvp.2015.04.003

Lichtenfeld, S., A.J. Elliot, M.A Maier, and R. Pekrun. 2012. Fertile green: Green facilitates creative performance. Persnal. Soc. Psychol. Bull. 38(6):784-797. https://doi.org/ $10.1177 / 0146167212436611$

Lopez, B., C. Kennedy, and T. McPhearson. 2020. Parks are critical urban infrastructure: Perception and use of urban green spaces in NYC during COVID-19. Preprints. https://doi.org/10.20944/preprints202008.0620.v1

Lumber, R., M. Richardson, and J.-A. Albertsen. 2018. HFE in Biophilic Design: Human Connections with Nature. In A. Thatcher and P.H.P Yeow (eds.), Ergonomics and Human Factors for a Sustainable Future: Current Research and Future Possibilities (pp. 161-190). Camden, UK: Palgrave Macmillan/Springer Nature.

Marcus, C. and N. Sachs. 2013. Therapeutic Landscapes: An Evidence-Based Approach to Designing Healing Gardens and Restorative Outdoor Spaces. John Wiley \& Sons.

Mehta, R., R. Zhu, and A. Cheema. 2012. Is noise always bad? Exploring the effects of ambient noise on creative cognition. J. Consum. Res. 39(4): 784-799. https://doi.org/10.1086/665048

Nicklas, M.H. and G.B. Bailey. 1996. Student performance in daylit schools. Raleigh, NC: Innovative Design. 
Retrieved from http://www.innovativedesign.net/wp-co ntent/uploads/2019/05/Analysis-of-Student-Performance -in-Daylit-Schools.pdf

Nieuwenhuis, M., C. Knight, T. Postmes, and S.A. Haslam. 2014. The relative benefits of green versus lean office space: Three field experiments. J. Exp. Psychol. Appl. 20(3):199-214. https://doi.org/10.1037/xap0000024

Nyrud, A.Q., T. Bringslimark, and K. Bysheim. 2014. Benefits from wood interior in a hospital room: A preference study. Archit. Sci. Rev. 57(2):125-131. https://doi.org/10.1080/00038628.2013.816933

Orsega-Smith, E., A.J. Mowen, L.L. Payne, and G. Godbey. 2004. The interaction of stress and park use on psychophysiological health in older adults. J. Leis. Res. 36(2): 232-256. https://doi.org/10.1080/00222216.2004.11950021

Pheasant, R.J., M.N. Fisher, G.R Watts, D.J. Whitaker, and K.V. Horoshenkov. 2010. The importance of auditory-visual interaction in the construction of 'tranquil space.' J. Environ. Psychol. 30(4):501-509. https://doi.org/10.1016/j.jenvp.2010.03.006

Qin, J., C. Sun, Z. Zhou, H. Leng, and Z. Lian. 2013. The effect of indoor plants on human comfort. Indoor Built Environ. 23(5):709-723. https://doi.org/10.1177/142032 6X13481372

Rapee, R.M. (1997). Perceived threat and perceived control as predictors of the degree of fear in physical and social situations. J. Anxiety Disord. 11(5):455-461. https://doi. org/10.1016/S0887-6185(97)00022-4

Ratcliffe, E., B. Gatersleben, and P.T. Sowden. 2013. Bird sounds and their contributions to perceived attention restoration and stress recovery. J. Environ. Psychol. 36:221-228. https://doi.org/10.1016/j.jenvp.2013.08.004

Reddy, S.M., D. Chakrabarti, and S. Karmakar. 2012. Emotion and interior space design: An ergonomic perspective. Work. Vol. 41(Suppl 1):1072-1078. https://doi.org/10.3 233/wor-2012-0284-1072

Ryan, C.O., W.D. Browning, J.O. Clancy, S.L. Andrews, and N.B. Kallianpurkar. 2014. Biophilic design patterns: Emerging nature-based parameters for health and well-being in the built environment. Archnet-IJAR. 8(2): 62-76. https://doi.org/10.26687/archnet-ijar.v8i2.436

Salingaros, N. A. 2013. Unified architectural theory: Form, language, complexity - a companion to Christopher Alexander's "the phenomenon of life: The nature of or- der, book 1". Portland, OR; Kathmandu, Nepal: Sustasis Press.

Schatz, S.L. and C.A. Bowers. 2005. 10 questions on room color: Answers for workplace designers. Ergon Des. 13(4):21-27. https://doi.org/10.1177/106480460501300406

Shoemaker, C. A., K. Randall, P.D. Relf, and E.S. Geller. 1992. Relationships between plants, behavior, and attitudes in an office environment. Horttechnology. 2(2): 205-206. https://doi.org/10.21273/HORTTECH.2.2.205

Thomsen, J.D., T., H. K. H. Sønderstrup-Andersen, and R. Müller. 2011. People-plant relationships in an office workplace: Perceived benefits for the workplace and employees. HortScience. 46(5):744-752. https://doi.org/ 10.21273/HORT SCI.46.5.744

Tsunetsugu, Y., Y. Miyazaki, and H. Sato. 2007. Physiological effects in humans induced by the visual stimulation of room interiors with different wood quantities. J. Wood Sci. 53(1):11-16. https://doi.org/10.1007/s10086-006-08 $12-5$

Ulrich, R.S. 1981. Natural versus urban scenes: Some psychophysiological effects. Environ. Behav. 13(5):523-556. https://doi.org/10.1177/0013916581135001

Ulrich, R.S. 1984. View through a window may influence recovery from surgery. Science. 224:420-421. https://doi. org/10.1126/science.6143402

Ulrich, R.S., R.F. Simons, B.D Losito, E. Fiorito, M.A. Miles, and M. Zelson. 1991. Stress recovery during exposure to natural and urban environments. J. Environ. Psychol. 11(3):201-230. https://doi.org/10.1016/S02724944(05)80184-7

van den Berg, A.E., S.L. Koole, and N.Y. Van der Wulp. 2003. Environmental preference and restoration: (How) are they related? J. Environ. Psychol. 23(2):135-146. https://doi.org/10.1016/S0272-4944(02)00111-1

van den Berg, A.E. and M. ter Heijne. 2005. Fear versus fascination: An exploration of emotional responses to natural threats. J. Environ. Psychol. 25(3):261-272. https://doi.org/10.1016/j.jenvp.2005.08.004

Van den Berg, A. E., T. Hartig, and H. Staats. 2007. Preference for nature in urbanized societies: Stress, restoration, and the pursuit of sustainability. J Soc Issues. 63(1): 79-96. https://doi.org/10.1111/j.1540-4560.2007.00497.x

Velarde, M.D., G. Fry, and M. Tveit. 2007. Health effects 
of viewing landscapes - Landscape types in environmental psychology. Urban For. Urban Green. 6(4): 199-212. https://doi.org/10.1016/j.ufug.2007.07.001

White, E.V. and B. Gatersleben. 2011. Greenery on residential buildings: Does it affect preferences and perceptions of beauty? J. Environ. Psychol. 31(1):89-98. https://doi. org/10.1016/j.jenvp.2010.11.002

White, M., A. Smith, K. Humphryes, S. Pahl, D. Snelling, and M. Depledge. 2010. Blue space: The importance of water for preference, affect, and restorativeness ratings of natural and built scenes. J. Environ. Psychol. 30(4):482-493. https://doi.org/10.1016/j.jenvp.2010.04.004

White, M.P., I. Alcock, J. Grellier, B.W. Wheeler, T. Hartig, S.L Warber, A. Bone, M.H. Depledge, and L.E. Fleming.
2019. Spending at least 120 minutes a week in nature is associated with good health and wellbeing. Sci. Rep. 9(1):7730. https://doi.org/10.1038/s41598-019-44097-3

Wilson, E.O. (1984). Biophilia. Cambridge, MA: Harvard University Press.

Windhager, S., K. Atzwanger, F.L. Bookstein, and K. Schaefer. 2011. Fish in a mall aquarium-An ethological investigation of biophilia. Landsc. Urban Plan. 99(1): 23-30. https://doi.org/10.1016/j.landurbplan.2010.08.008

Zadeh, R.S., M.M. Shepley, G. Williams, and S.S. Chung. 2014. The impact of windows and daylight on acute-care nurses' physiological, psychological, and behavioral health. HERD, 7(4):35-61. https://doi.org/10.1177/1937 58671400700405 